\title{
SOCIO-ECONOMIC CONSEQUENCES OF TECHNICAL CHANGE IN Palm Fruit Processing in Osun State, Nigeria
}

T Alimi, A S Bamire and A B Ayanwale

Agricultural Economics Department, Faculty of Agriculture, Obafemi Awolowo University, Nigeria.

\begin{abstract}
The traditional palm fruit processing method is basically manual, but is currently undergoing changes. This study identifies the stages that have been mechanised in traditional processing methods and the socio-economic implications of the technical change to assist decision-making on the superiority or otherwise of the mechanised (modern) method over the traditional method used by processors in Osun State of Nigeria. Primary data were collected during the 2004 production season with the aid of a structured questionnaire on the production resources and outputs of the two methods. These were analysed using descriptive and inferential statistics, budgetary technique dominance and sensitivity analyses, and attitudinal measure.

Results indicate that only two (pounding to form paste and cracking) of the stages identified in the traditional method were mechanised in the modern method. This resulted in greater efficiency of palm oil extraction, higher labour productivity, more income to stakeholders, greater market orientation, increased volume of operation and unchanged product types and quality. Other consequences are the creation of one additional group of stakeholders (machine owners), dominance, resilience to adverse yield and machine charges by 27 per cent and 150 per cent, respectively; more favourable attitude, less drudgery and health hazards, less labour requirements (female) and lower processing time in the modern method than the traditional method. This made the modern method a better choice, which could boost palm oil production at the aggregate level.
\end{abstract}

JEL 014

Key words: Oil palm fruit, processing, technical change, efficiency, attitude

Running title: Effects of technical change in processing

\section{1}

\section{Introduction}

Every nation strives to achieve economic development, as this determines the success of a nation. Economic development is the process by which a population increases the efficiency with which it provides desired goods and services, thereby increasing per capita levels of living and general well-being (Mellor, 1966; Jhingan, 2003). For an agrarian economy like Nigeria to have sustained economic development, agricultural development is a prerequisite because of the role of agriculture in the economic development process. Among other things, agriculture provides food for the teeming population, generates foreign exchange earnings from exports, provides raw materials for agro-allied industries, serves as market for industrial products, and releases labour to nonagricultural sectors (Fabiyi, 1979; Ajakaiye \& Akande, 1999).

Agricultural development simply means an increase in agricultural productivity and the total well being of the farm populace. One way of achieving higher productivity in agriculture and general economic development is through improved farming technologies (Briggs \& Farrington, 1991). Technology is the society's 
pool of knowledge regarding the industrial arts, which consists of the principles of physical and social phenomena and their application in dayto-day production operations. Either technological change, which is new knowledge about techniques (advance in knowledge), or technical change, which is the adaptation of new techniques (alteration in the character of the equipment, product and organisation), or both, must exist to raise productivity (OyelaranOyeyinka et.al, 1995). Technical change is more common in developing countries because of their low level of advanced science and technology.

The oil palm is a particularly important industrial crop (source of palmitic and lauric acid, rich industrial and domestic edible oils and substantial biomass) in which Nigeria and some other African countries such as Cameroun and Zaire used to be leading producers. It is the second-largest (20.8 per cent of all output) vegetable oil source in the world after soyabean, and it considerably out-yields other crops in oil (6t/ha) and biomass (24t/ha) per hectare (Murphy, 1994). Though global production of palm oil has quadrupled in the last twenty-five years, Nigeria's production is less than double, with an unstable annual marginal increase even when the price rise was about two thousand percent (CBN, 1997). The bulk of production (80 per cent) now comes from the Pacific Rim countries, particularly Malaysia and Indonesia, who are investing considerable amounts in the development of production and processing technology. In addition to vigorous export promotion, these countries are reaping the benefits of downstream exploitation in the oleo chemical and dependent consumer goods industries.

Unhappy about the turn of fortunes, Nigeria has been making efforts to regain its pride of place in palm oil production by promoting the development and adoption of small-scale palm fruit extraction technologies. Today we can identify various categories of palm oil processors and they are: those who for various reasons are still stuck with the conventional traditional method, those who have adopted the small-scale technology, and some few largescale palm oil mills employing more modern technology. This paper focuses on the socioeconomic impact of the adoption of small-scale palm fruit processing technology on the primary stakeholders in the industry. The overall goal is to identify the better method between the traditional and the mechanised small-scale (modern) palm fruit processing method for support/promotion.

There are divergent views on agricultural mechanisation policy prescriptions for developing countries. While some hold the opinion that mechanisation is the key to increased productivity in African agriculture, others express concern about premature mechanisation in the labour-abundant economies of developing nations. However, there is general consensus that changes in production techniques are known to have economic/social consequences that can be either desirable or undesirable (Muqtada, 1975; Ladipo \& Adeyemo, 1981; Akinyemiju \& Alimi, 1988; Alimi et al., 1990; Alimi \& Alofe, 1992). This study will contribute to this debate and hopefully generate new empirical data with respect to the processing of agro-industrial raw materials.

Changes in production techniques, apart from affecting physical productivity, can also affect the actual and/or perceived quality of the products. Perception is the way individuals or groups see things, which may be different from what those things actually are. Perception influences behaviour and is determined by needs. Muqtada (1975) observed a relative price-ratio between the output of High Yield Variety (HYV) and the local rice variety in favour of local variety because of perceived taste. Jibowo (1993), in discussing the influence of culture (taste and preferences) on the acceptability of new products, stated that highyielding yellow maize introduced to Western Nigerian farmers in the 1960s had to be discontinued, despite its higher productivity, because of the consumers' preference for white maize products. Also, the demand for unfertilized eggs of exotic poultry breeds was low in the 1960s because women of childbearing age were prevented from consuming the eggs, as it was culturally believed that it could cause sterility in women. This study will compare the 
perceived quality of the products of the modern method with the traditional method of palm fruit processing.

The known studies on palm production and processing in South-Western Nigeria, including Osun State, focused on agronomic improvement and some technical aspects of traditional palm oil processing (Opeke, 1982), and at best on the economics of traditional palm oil production (Oguntade, 1984; Alimi \& Ayanwale, 1998). Alimi and Ayanwale (1998), in an investigation of the economics of traditional palm oil production, identified three major stakeholders as palm tree owners, palm fruit harvesters and palm fruit processors. Male persons dominated the first two categories, while traditional processing was exclusively the domain of female persons. The issue that could be raised at this stage is what happens to the input contributions and income accruing to female persons with a change in processing technology. Asked in another form, does technical change in the palm fruit processing industry bring about change in input contributions and income distribution accruing to males and females?

From the foregoing, the research problems in this study centered on the following questions:

(i) What is the effect of technical change in palm fruit processing on income and labour requirements?

(ii) Does technical change affect the drudgery and market orientation of processors?

(iii) What are the profitability and labour productivity of the processing techniques?

(iv) Does technical change bring about any significant change in the perceived quality of the products derived from the processing methods?

Providing answers to these questions will inform policy-makers on the need to encourage the technical change that would enhance productivity in palm fruit processing and the general well being of the stakeholders.

2

Research methodology

\subsection{Methodological concepts}

The production process is that in which some goods and services, called inputs, are transformed into other goods and services, called output (Olayide \& Heady, 1982). The physical inputs in agriculture could be grouped into land, labour and capital. These resources are organised by a farming business (a unit of production) to obtain output used to realise the farming business's objectives. The input-output systems approach indicates that production generally has three main components: inputs, resource conversion unit and output. The resources that are combined in a particular input mix flow into the farm-firm that organises their conversion into output. The nature of output determines the feedback that may lead to the modification/change in inputs and resource conversion unit for improved performance. The components of oil-palm fruit processing system, on which modern and traditional palm fruit processing methods are compared, are indicated in Figure 1. Each of the two categories of inputs conversion unit (traditional and modern contract processors) organises inputs to produce outputs. The basic categories of inputs are materials (mainly oil palm fruit), labour (family and hired, gender and payment modes), and capital (types, quantity of equipments and machine hours). The outputs (outcomes of a production process) are physical product types and quality, efficiency, attitudes, labour requirement, level of drudgery, profitability, income distribution and market orientation. 


\section{Figure 1}

Model for evaluation of technical change in palm fruit processing in Osun State, Nigeria

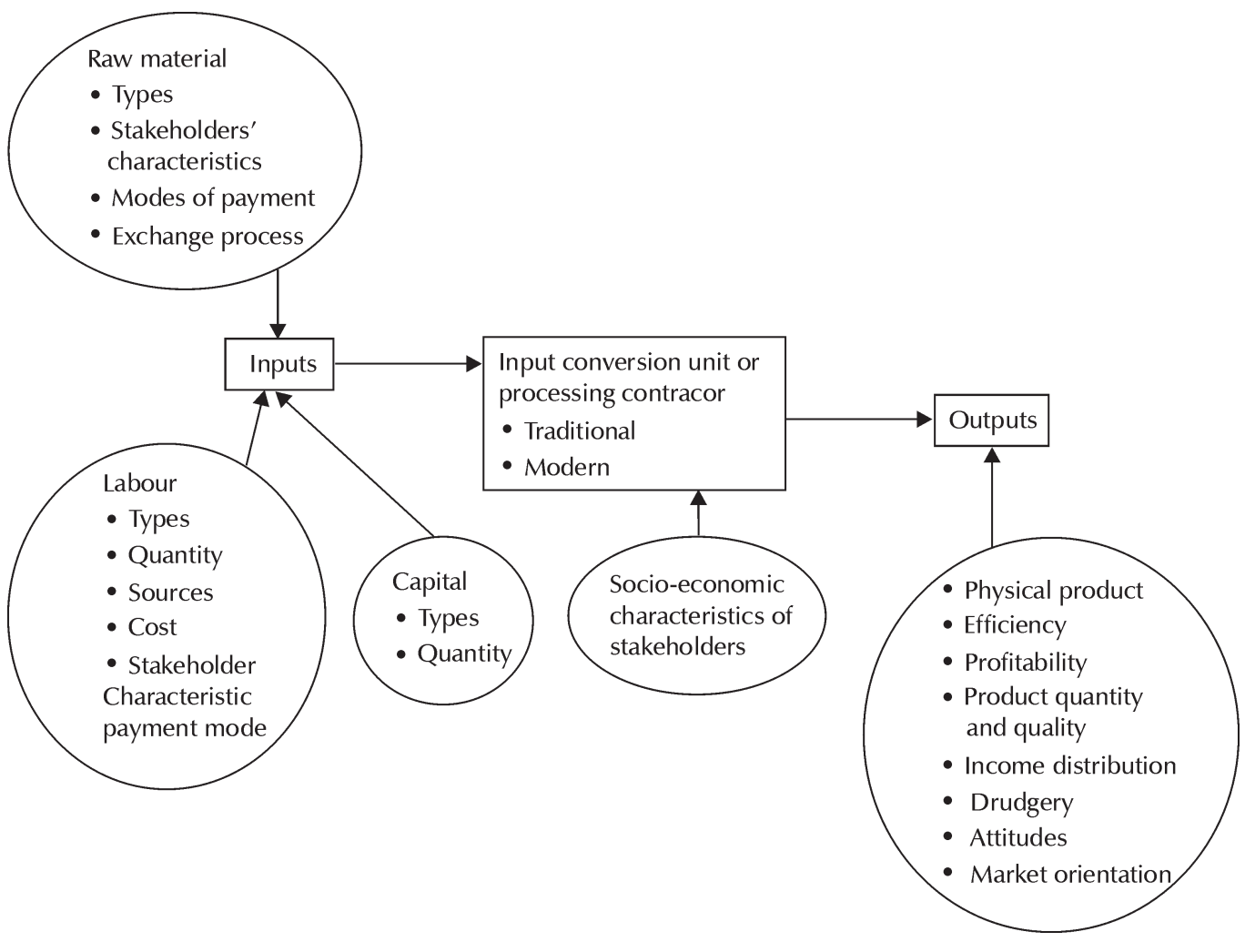

Source: Adapted from Olayide and Heady (1982)

\subsection{Definition of terms}

Processing-contractor: The entrepreneur who organises factors of production in the harvesting and processing of oil-palm fruit to obtain palm produce.

Hired labour processors: These are skilled processors whose services are obtained for remuneration (payment in cash and kind) by the processing-contractor. Unlike family labour, this type of labour passes through the labour market exchange process.

Processing machine owners: This are owners of processing plant/machine patronized by modern processing-contractors for the use of processing machine facilities.

Modern processing method: A partially mechanised processing method.

Traditional processing method: The age-long processing method that is basically manual/ labour intensive.
A processing run: The processing of a batch of raw material (palm fruit). The quantity of palm fruit for a batch is a drum with a volume of 250 litres with a cone of about 20 per cent of the drum. The volume of palm fruit for a processing run is 300 litres. The bulk density of palm fruit is $0.540 \mathrm{~kg} / \mathrm{litre}$. The weight of the fruit for a processing run is thus approximately $162 \mathrm{~kg}$.

Processing cycle: The processing of the entire quantity of palm fruit taken to the site at the end of each harvest.

Number of processing cycles per annum: The number of times in a year that a processingcontractor carries out harvesting, and processes at the processing centre.

A man-day of labour: A full day's work by an adult processor.

Family labour: Labour assistance obtained by the processing-contractor from his/her 
household. This type of labour does not pass through the labour market exchange process and thus attracts no payment.

Gender-dominated enterprise: An enterprise is considered dominated by a particular gender if that gender accounts for more than half of the entrepreneurs in the enterprise.

\subsection{Data collection and sampling technique}

Nested sampling technique with simple random sampling at each stage (Steel \& Torrie, 1960) was used to select processing-contractors in 2004. The first stage was the selection of two local government areas in Osun State of Nigeria. The second stage was the compilation of separate lists of the sites of processors that use modern and traditional processing methods. Selection of twenty percent of each of the two categories of the processing sites was the next stage. In the fourth (last) stage a list of the processing contractors in each processing site was obtained and 50 per cent of the processing contractors were selected. The processing contractors selected assisted in identifying the oil-palm tree owners (one oil-palm tree owner randomly selected if a processing contractor has more than one oil-palm tree owner), hired labour processors and palm bunch harvesters. Thus, the target populations are processing contractors, hired processors, oil-palm tree owners and palm bunch harvesters. The questionnaires administered solicited data on socio-economic characteristics of each category of respondents. In addition, processing contractors provided data on the inputs and outputs of processing and their (hired processors inclusive) attitudes towards modern processing methods.

\subsection{Data analytical techniques}

Analytical methods used on primary data collected were descriptive and inferential statistics, enterprise budgeting technique, dominance and sensitivity analyses, and attitudinal measure.

\subsubsection{Descriptive and inferential statistics}

Descriptive statistics are concerned with the frequency distribution, and the mean and standard deviation values of relevant variables of the palm fruit processing methods. The inferential statistics of t-test of differences between two mean values tested at 5 per cent level of significance were used to determine differences in the mean values of each variable of interest of the two processing technologies (Daniel \& Terrell, 1979).

\subsubsection{Enterprise budgeting technique}

Enterprise budgeting is the listing of income, expenses/costs and profit of the farming business on a per unit basis (Harsh et al., 1981). Each enterprise's budget is developed on a single common unit, such as hectares for crops or head for livestock. (Alimi \& Manyong, 2000). The single common unit for this study on which the two processing methods are compared, is a drum (300 litres or $162 \mathrm{~kg}$ ) of palm fruit. An enterprise's budget allows comparison of profits or profitability among enterprises on the same farm or with different technologies. The income, expenses and profit of each of the two processing methods were computed and compared to identify the better method in terms of profit/profitability.

\subsubsection{Dominance and sensitivity analyses}

The process of eliminating dominated technology from further selection analysis is called dominance analysis. A dominated technology has the same or lower net benefit (net income) than other technologies of a lower total variable input cost (Alimi \& Manyong, 2000). Dominance analysis establishes the economic superiority of one technology over the other(s). Certain factors beyond the control of the farmers (entrepreneurs) could negatively affect the net benefit and the marginal rate of return when shifting from the present practice to a proposed practice. Examples of these factors are technology failure, which could reduce yield, and a change in the market situation leading to a reduction in net income. These factors bring about risk or uncertainty associated with the proposed technology. 
Sensitivity analysis is used to test the ability of a proposed technology to withstand adverse yield or price changes (CIMMYT, 1988).

\subsubsection{Attitudinalmeasure}

To determine the attitude of palm fruit processors and hired processors towards modern palm fruit processing methods, a set of ten pre-tested and validated attitudinal statements against a 5-point Likert attitudinal scale viz: Strongly agreed (5), agreed (4), undecided (3), disagreed (2), and strongly disagreed (1) was drawn (Leavitt, 1978). The responses of the processors to the statements were collected and analysed using attitudinal measure.

Attitudinal measure involves scoring each declarative statement for each palm fruit processor $\left(\mathrm{Y}_{\mathrm{ij}}\right)$ and computing the total score on all the declarative statements $\left(\mathrm{Y}_{\mathrm{i}}\right)$ as stated in Table 1.

\section{Table 1}

Score of palm fruit processors on Likert Attitudinal Scale

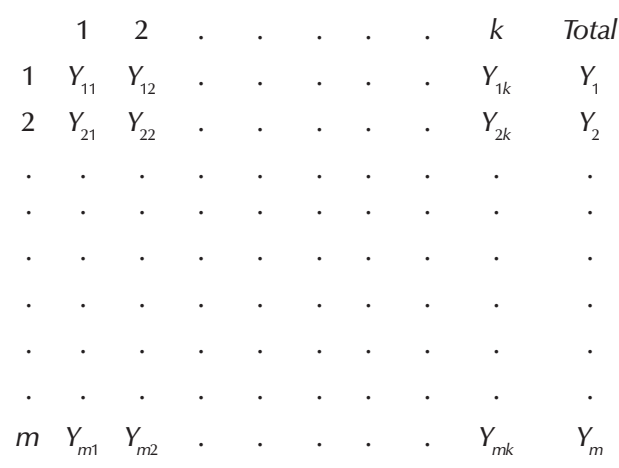

Such that:

$\mathrm{n}(\mathrm{F})=\mathrm{n}\left(\mathrm{Y}_{\mathrm{i} .}{ }^{3} 0.5 \mathrm{tk}\right)$

$\mathrm{n}(\mathrm{U})=\mathrm{n}\left(\mathrm{Y}_{\mathrm{i} .}<0.5 \mathrm{tk}\right)$

where:

$\mathrm{n}(\mathrm{F})=$ number of processors showing a favourable attitude towards the modern method. $\mathrm{n}(\mathrm{U})=$ number of processors indicating unfavourable attitude towards the modern method.

$t$ is the maximum score (5) on each declarative statement.

$\mathrm{i}=1,2, \ldots \ldots \mathrm{m}$

$\mathrm{j}=1,2, \ldots \ldots \mathrm{k}$ $\mathrm{m}$ is the sample size of processors

$\mathrm{k}$ is the number of declarative statements

The decision rule is that an individual is considered to have a favourable attitude if his/ her total score is at least half of the maximum score obtainable (tk), otherwise he/she has an unfavourable attitude. In this study there are ten (k) declarative statements on the use of modern processing methods. Each declarative statement carries a maximum of five $(t)$ points. The maximum obtainable score (points) for a processor is fifty (tk). Thus, by the stipulated decision rule, a processor has a favourable attitude if his total score is at least 25 ; otherwise, an unfavourable attitude is recorded.

3

\section{Results and discussion}

\subsection{Sample sizes of respondents}

A total of 92 processing-contractors were interviewed, out of which 48 used the traditional method and the remaining (43) the modern method. The sample size of palm tree owners was 92 , while the sample sizes of palm bunch harvesters and hired processors were 21 and 306 , respectively.

\subsection{Physical inputs and outputs of a processing run}

The production stages and the mean and standard deviation values of palm fruit processing variables for a processing run in the two methods are stated in Figure 2 and Table 2, respectively. Twelve processing stages were identified (Figure 2). In the traditional method, all the stages were exclusively for females and manual. Alimi and Ayanwale (1998) and Taiwo et al., (2000) noted that traditional palm fruit processing was a female-dominated enterprise. All the processing stages in the modern method are identical to the traditional processing method, except the transportation of fruit to the processing centre, pounding of fruit into paste and palm kernel cracking stages. While the transportation of oil palm fruit to the processing centre was with head portage in the traditional method, it was by motor vehicle in the modern 
method because of long distance between the palm fruit collection centre and locality of the processing machine facility. The modern method made use of processing machine facilities in the digestion of fruit and palm kernel cracking stages. While digestion and palm kernel cracking consumed approximately 3 and 7 man-days respectively of human labour, the processing machine facility takes approximately two and one hour for digestion and cracking, respectively (Table 2). The mean number of bunches for a production run (a drum) was approximately twenty-five. The physical outputs of production can be divided into three categories: palm oil, palm kernel and byproducts. The mean quantity of palm oil obtained from a production run using the traditional method was 19.7 litres, while that of the modern method was 25.2 litres. The mean quantities of cracked palm kernel obtained from traditional and modern methods were 69.7 and $70.4 \mathrm{~kg}$, respectively, and revenues from byproducts were $\$ 1012$ and $\$ 1026$ for traditional and modern methods, respectively.

Figure 2

Palm fruit processing flow chart in Osun State, Nigeria

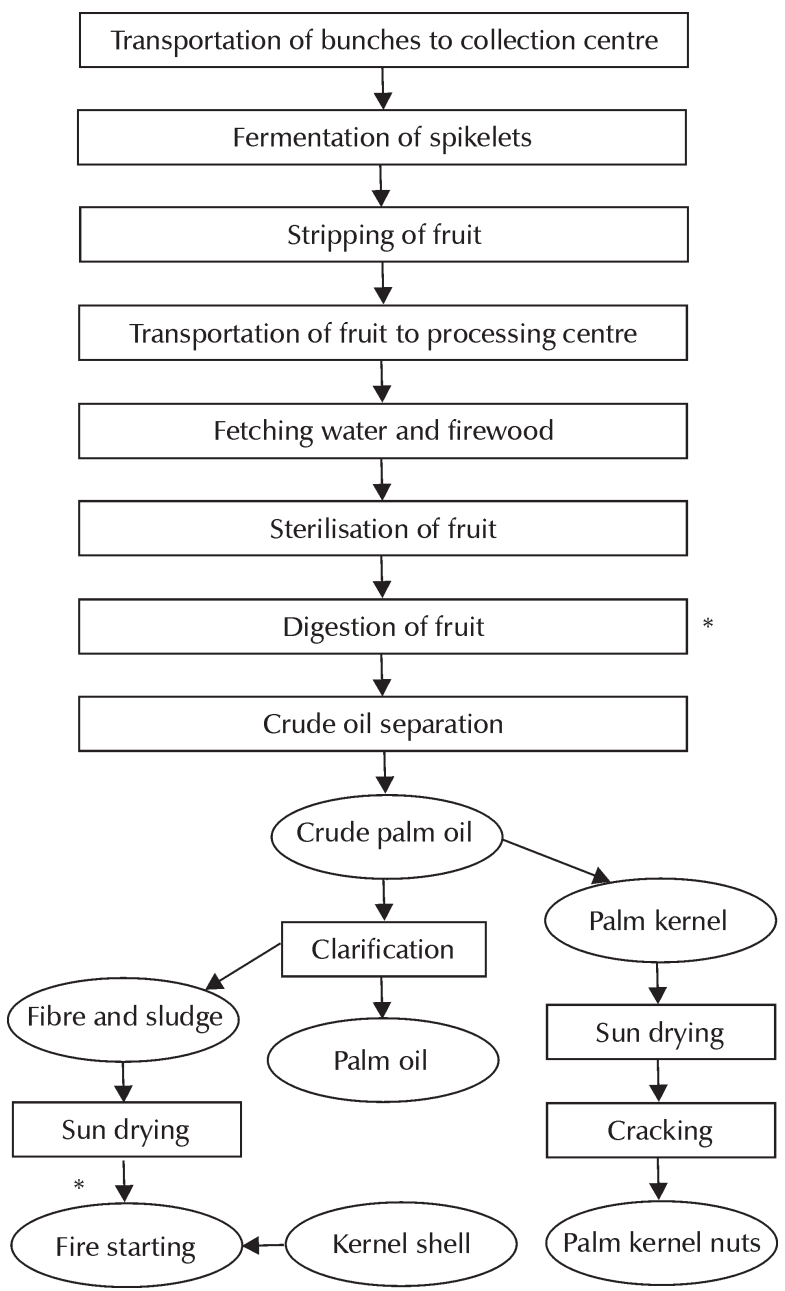

Notes: Inside each rectangle is the activity performed at that processing stage. Each circle contains the product(s) obtained from the preceding activity. * means mechanised stages adopted in modern method. 


\section{Table 2}

Mean and standard deviation values of palm fruit processing variables for a processing run in Osun State, Nigeria

\begin{tabular}{|c|c|c|c|c|c|c|}
\hline Variables & Unit & Traditional & & Modern & $\mathbf{t}_{\mathrm{c}}$ & \\
\hline & & $\bar{X}_{1}$ & $\mathrm{~S}_{1}$ & $\bar{X}_{2}$ & $\mathrm{~S}_{2}$ & \\
\hline Output: Palm oil & litre & 19.7 & 2.22 & 25.2 & 1.83 & $12.94^{*}$ \\
\hline Palm kernel & $\mathrm{kg}$ & 69.7 & 3.59 & 70.4 & 4.72 & .79 \\
\hline By-product & $A$ & 1012.0 & 101 & 1026 & 85 & .72 \\
\hline \multicolumn{7}{|l|}{ Inputs: } \\
\hline Number of bunches per drum & & 24.8 & 2.32 & & & \\
\hline $\begin{array}{l}\text { Transportation of bunches to } \\
\text { collection centre }\end{array}$ & $\mathrm{m} /$ day & 1.0 & 0.13 & & & \\
\hline Stripping of fruit & $\mathrm{m} /$ day & 2.1 & 0.35 & & & \\
\hline $\begin{array}{l}\text { Transportation of fruit to } \\
\text { processing centre }\end{array}$ & $\mathrm{m} /$ day & 1.1 & 0.27 & & & \\
\hline Fetching water and firewood & $\mathrm{m} /$ day & 0.9 & 0.26 & & & \\
\hline Supervision of boiling & $\mathrm{m} /$ day & 0.5 & 0.09 & & & \\
\hline Digestion & & 3.1 & 0.22 & $1.93^{* *}$ & 0.22 & \\
\hline Skimming & $\mathrm{m} /$ day & 0.9 & 0.21 & & & \\
\hline Clarifying & $\mathrm{m} /$ day & 1.1 & 0.13 & & & \\
\hline Obtaining various by-products & $\mathrm{m} /$ day & 1.2 & 0.29 & & & \\
\hline Cracking of palm kernel & $\mathrm{m} /$ day & 7.3 & 1.34 & $0.9^{* *}$ & 0.15 & \\
\hline
\end{tabular}

* means significant at 5 per cent level

** means machine hours

Source: Data Analysis, 2004

\subsection{Inputs of palm fruit processing}

The inputs used in palm fruit processing activities can be grouped into raw materials, labour and capital.

\subsubsection{Raw materials and stakeholders}

The main raw material is oil palm fruit. There are two major stakeholders in the supply of oil palm fruit, viz. the oil palm tree owners and the palm tree harvesters. The socio-economic characteristics of oil palm tree owners and harvesters are indicated in Table 3. 


\section{Table 3}

Socio-economic characteristics of major stakeholders in palm fruit processing by gender in Osun State, Nigeria

\begin{tabular}{|c|c|c|}
\hline \multirow[t]{2}{*}{ Characteristics } & \multicolumn{2}{|c|}{ Distribution by gender (\%) } \\
\hline & Male & Female \\
\hline \multicolumn{3}{|l|}{ Palm tree owners $(\mathrm{n}=92)$} \\
\hline Sex & 76.2 & 23.8 \\
\hline Mean age (years) & $65(10.3)$ & $48(8.6)$ \\
\hline \multicolumn{3}{|l|}{ Ownership pattern: } \\
\hline Inheritance & 75.1 & 4.4 \\
\hline Purchase & 1.1 & 19.4 \\
\hline \multicolumn{3}{|l|}{ Owner harvester: } \\
\hline Yes & 2.2 & Nil \\
\hline No & 74.0 & 23.8 \\
\hline \multicolumn{3}{|l|}{ Owner processor: } \\
\hline Yes & Nil & 10.9 \\
\hline No & 76.2 & 12.9 \\
\hline \multicolumn{3}{|l|}{ Literacy level: } \\
\hline Literate & 8.7 & 6.5 \\
\hline Illiterate & 67.5 & 7.3 \\
\hline Mean number of trees per owner & $265(40)$ & $148(32)$ \\
\hline \multicolumn{3}{|l|}{ Harvesters $(\mathrm{n}=21)$} \\
\hline Sex & 100 & \\
\hline Mean age (years) & 42 & \\
\hline \multicolumn{3}{|l|}{ Literacy level: } \\
\hline Literate & 9.5 & \\
\hline Illiterate & 90.5 & \\
\hline
\end{tabular}

The figures in brackets are the standard deviation

\subsubsection{Oil palm tree owners}

A high proportion (76.2 per cent) of the owners is male. About four-fifths (79.5 per cent) of the owners got ownership through inheritance and the rest by purchase. Most of the female owners purchased the oil palm trees, while a high proportion of males inherited them. This is due to the inheritance system operating in the study area that favours males above females. None of the female owners was an owner-harvester and only 2.2 per cent owner-harvesters were male while the remaining were females. This shows that owners do not participate so much in the harvesting of oil palm trees. None of the male owners was owner-processor. Only 10.9 per cent owner processors were female. This implies that 89.1 per cent of the owners did not take part in the processing of palm fruit, but obtained the services of processing contractors. Apart from the larger proportion of palm tree owners being male, the mean number of trees owned by males (265) is significantly higher than that of females (148). The larger proportion of males (owning palm trees) and the larger mean 
number of palm trees owned by males relative to females make palm tree ownership male dominated. Palm tree owners are paid rent in kind (10 per cent of palm oil produced) when processing is given out to processing contractors. The stakeholders (palm tree owners and harvesters) in the supply of raw material (palm fruit) are similar in the two processing methods. No market is yet in operation in the study area for the exchange of either palm fruit bunches or palm fruit.

\subsubsection{Palm fruit harvesters}

The palm fruit bunch harvesters are all male and skilled in the exercise. Their mean age is 42 years and they are largely illiterate. The tediousness involved in the climbing of palm trees and the dangers of being attacked by wild animals in the harvesting process prevent females from harvesting palm bunches. The harvesters are paid in cash at $\$ 150$ per tree for palm tree base clearing/crown preparation, $\$ 15$ per bunch harvested and $\$ 100$ per day in lieu of food.

\subsubsection{Labour}

Labour is the physical human energy used in the production process. Female persons (processors) supply all the labour needed in the two processing methods. They are largely illiterate with a mean age of 44.6 years. The traditional method is more labour intensive as capital (machine hours) is substituted for labour in the modern method. In a production run, the mean labour used in the traditional method is 18.53 man-days, which comes to 8.3 man-days in the modern method (Table 4). Both traditional and modern methods use hired and family labour. The levels of hired labour are higher in the modern method than the traditional method. In a processing run, the absolute and proportional values of hired labour were 5.3 mandays and 0.2523 , respectively with the traditional method against 6.9 man-days and 0.8625 , respectively with the modern method. The processing group size was significantly higher in the traditional method than the modern methods. The mean group size was 5.4 in the traditional method and 3.2 in the modern method. The lower processing group size in the modern method was due to its lower labour requirements relative to the traditional method. Hired processors were paid in both cash and kind. They received 60 per cent of the palm oil, 25 per cent of the cracked palm kernel, 50 per cent of the by-products and $\$ 100$ per day in lieu of food in the traditional method. In the modern method, they received 60 per cent of the palm oil, $4 \mathrm{~kg}$ (6.06 per cent) of the cracked palm kernel, half of the by-products and $\$ 100$ per day in lieu of food.

\section{Table 4}

Mean/Proportion values of socio-economic characteristics of processing enterprise/ processing contractors by processing methods in Osun State, Nigeria

\begin{tabular}{|l|c|c|c|}
\hline Characteristics & \multicolumn{3}{l|}{ Processing methods } \\
\hline $\mathrm{n}$ & Traditional & Modern & $\mathbf{t}_{\mathbf{c}}$ \\
\hline Age (years) & 48 & 43 & $2.31^{*}$ \\
\hline Literacy (years) & $51(5.3)$ & $48(6.9)$ & $8.13^{*}$ \\
\hline Processing group size & $3.4(2.3)$ & $9.6(4.5)$ & $6.07^{*}$ \\
\hline Number of processing runs/processing duration cycle & $5.4(2.1)$ & $3.2(1.3)$ & $10.87^{*}$ \\
\hline Number of trees handled/year/ processing group & $1.1(0.6)$ & $3.3(1.2)$ & $26.50^{*}$ \\
\hline Proportion of palm oil sold & $98.3(34.4)$ & $512.6(77.2)$ & $12.17^{*}$ \\
\hline Number of processing periods/year & $0.45(0.14)$ & $0.82(0.15)$ & $15.04^{*}$ \\
\hline Man-days of labour/run & $11(2.3)$ & $25(5.7)$ & $20.98^{*}$ \\
\hline
\end{tabular}




\begin{tabular}{|l|c|c|c|}
\hline Machine hour/run & & $3(0.3)$ & \\
\hline Proportion of processors owning palm tress & 0.26 & 0.61 & $3.71^{*}$ \\
\hline Man-days of hired labour/run & $5.3(2.3)$ & $6.9(1.8)$ & 100 \\
\hline Ownership pattern: single & 100 & 100 & \\
\hline Sex: female & 100 & 100 \\
\hline
\end{tabular}

* Significant at 5 per cent level

Source: Data Analysis, 2004

\subsubsection{Capital}

The capital owned and used by the operators (processing contractors) under each of the two methods was low. Capital items include drums, cutlasses, knives, buckets, baskets and bowls. Each processing group has an average of one drum, two cutlasses, two knives, two buckets, four baskets and three bowls. The mean quantities of each of the capital items are not significantly different between the two methods.

\subsection{Input conversion unit}

Table 4 shows the socio-economic characteristics (mean/proportion values) of processing enterprises and processing contractors. Ownership pattern in the two methods was single proprietorship and all the entrepreneurs were female. The processing contractors using the modern method were significantly younger and more literate than those using the traditional method. The mean age of processing contractors in the modern method was 48 years, which is significantly lower than the mean age (51 years) of the processors using the traditional method. The mean literacy level (measured in number of years of formal education) for modern processing contractors (9.6) was higher than that of traditional processing contractors (3.4).

\subsection{Output}

The output of technical change in palm fruit processing was measured along these parameters: viz types and quality of physical output, market orientation, and volume of operation, drudgery, profit/profitability, involvement and return to gender, physical efficiency, and attitudes towards modern processing methods.

\subsubsection{Types and quality of products}

The same types of products (palm oil, palm kernel and by-products) were obtained, in both processing methods. The respondents, who were both producers and consumers, observed no difference in the quality of output.

\subsubsection{Extraction efficiency of palm products}

With the exception of palm oil, there was no significant difference in the mean quantities of output of cracked palm kernel obtained by the two processing methods or in the mean revenues of the by-products (Table 2). The mean quantity of palm oil obtained in the modern method was 25.2 litres, which is significantly higher than that of the traditional method (19.7 litres). This showed that palm oil extraction efficiency was higher with the modern method than the traditional method.

\subsubsection{Orientation of inputs and outputs}

The main raw material (palm fruit) of production did not pass through the market exchange system (did not have an input market). Although the processing group size using the modern method was smaller than that of the traditional method, the mean man-days of hired labour per run were significantly higher for the modern method (6.9) than the traditional method (5.3). This indicates that the modern method is more market oriented in labour input. The mean proportion of palm oil sold by the processors using the modern method (0.83) was significantly more than the traditional method (0.45), showing proportionally that the modern method is more market oriented than the traditional method.

\subsubsection{Volume of operation}

The mean number of processing runs in a processing cycle by entrepreneurs using the 
modern method was 3.3 , which is significantly higher than 1,1 of the traditional method. The mean number of processing cycles per year for the modern methods was 25 , which is significantly higher and more than doubles that of the traditional method (11). The mean number of oil palm trees handled per annum by traditional processing contractors was 98.3 , which is significantly lower and about 19.18 per cent of the processing-contractors using the modern method (512.6). The higher number of palm trees handled annually was responsible for the higher number of runs per cycle and the higher number of processing cycles per year in the modern method, thus the higher volume of operation. This is probably because of the higher speed of processing emanating from partial mechanisation in the modern method, thereby allowing for more effective exploitation of oil palm tree resources.

\subsubsection{Drudgery in processing and health of processors}

Users of the modern processing method claimed a reduction in the level of drudgery associated with traditional processing. This is due to the physical exhaustion of pounding and mashing in manual digestion, while bruises in the feet suffered in the traditional method are completely eliminated with the modern method. Also, the drudgery experienced in the manual cracking of palm kernel nuts is eliminated by mechanisation in the modern method.

\subsubsection{Allocation of revenue/income realised}

\subsubsection{By processing methods: Dominance and Sensitivity Analyses}

The total income realised using the modern method (7026) is higher than the income
( $\$ 6512$ ) in the traditional method (Table 5). The price per litre of palm oil was $\$ 100$ and price per $\mathrm{kg}$ of cracked palm kernel was $\$ 50$ for both methods since there was no difference in the quality of outputs. The difference in income was as a result of the difference in the efficiency of palm oil extraction, which was higher for the modern method (Table 2). The modern method resulted in lower total variable input cost ( $\$ 5234$ ) than the traditional method (\$5406). If the same level of risk is assumed for the two methods and using dominance analysis, the modern method dominated the traditional method because it (modern method) recorded relatively lower variable input cost and higher net income than the traditional method. For the dominance to be eliminated, the total variable input cost of the modern method would be higher than that of the traditional method by an additional $\$ 168$, which was the cost saving by the modern method. Sensitivity analysis indicates that at the same risk level for the two methods, the yield of palm oil will decrease by more than 6.82 litres $(27.28$ per cent), or machine charges would increase by more than \#682 (151.5 per cent) to make changing to the modern methods irrational. Assuming there is a risk in changing to the modern method, the acceptable rate of return is 50 per cent of the machine charges, and sensitivity analysis reveals that the palm oil yield would decline by more than 4.57 litres or machine charges would rise by more than 101 per cent to make the traditional method economically superior to the modern method. The increase in the level of risk of the modern method over the traditional method will reduce the superiority of the modern method.

\section{Table 5}

Enterprise budgets ( of palm fruit processing of a processing run in Osun State, Nigeria

\begin{tabular}{|l|l|l|}
\hline Items & Traditional & Modern \\
\hline Income: Palm oil & 2000 & 2500 \\
\hline Palm kernel & 3500 & 3500 \\
\hline By-products & 1012 & 1026 \\
\hline Total income & & \\
\hline
\end{tabular}




\begin{tabular}{|l|c|c|}
\hline Variable Input Cost: & 6512 & 7026 \\
\hline Costs: & & \\
\hline Pre-processing expenses: & 500 & 500 \\
\hline Palm tree base clearing & 475 & 475 \\
\hline Bunch harvesting & & 300 \\
\hline Post- harvest expenses: & & 2213 \\
\hline Transportation of fruit to processing centre & 2581 & 450 \\
\hline Labour & & 300 \\
\hline Machine charges & 500 & 750 \\
\hline Feeding of processors 100 per day & 1150 & 250 \\
\hline Rent (owner) & 200 & 1788 \\
\hline Total 5406 & 5238 & 225 \\
\hline Net income & 1106 & 1563 \\
\hline Risk (50\% of machine charges) & & \\
\hline Net income after considering risk & & \\
\hline
\end{tabular}

Source: Data Analysis, 2004

\subsubsection{By categories of personnel}

Only two categories of personnel were involved in the traditional method. These are the hired processors and the processing contractors. The modern method resulted in the creation of an additional category of personnel (new stakeholders-machine owners). There was a decline in the net earnings of hired processors from $\$ 3731$ in the traditional method to $\$ 2963$ in the modern method (Table 6). However, the modern method had a higher labour efficiency (net earnings per man-day) of hired processors (370.38) than the traditional method (201.7), indicating the superiority of the modern method over the traditional method in terms of returns to labour (Tables $2 \& 6$ ). The net income (earning) of processing contractors in the modern method was $\$ 1788$, which was almost three-fifths higher than that of the traditional processing contractors (Table 5). The higher earnings realised by processing contractors in the modern method is the return (compensation) for taking the risk of technological change which, if not below the expectation of the processing contractors, will encourage the use of the modern method. The amount of revenue accruing to the machineowner in the modern method was $\$ 40$ per processing run, which was made up of 10 per cent of palm oil extracted and $4 \mathrm{~kg}$ of cracked palm kernel. 


\section{Table 6}

Revenue in each processing method allocated by revenue sources, gender and categories of personnel in Osun State, Nigeria

\begin{tabular}{|c|c|c|c|c|}
\hline \multirow{2}{*}{$\begin{array}{l}\text { Revenue allocation } \\
\text { categories }\end{array}$} & \multicolumn{3}{|c|}{ Processing Personnel by Gender } & \multirow[t]{2}{*}{ Total } \\
\hline & Male & & Female & \\
\hline & $\begin{array}{l}\text { Processing } \\
\text { machine owner }\end{array}$ & $\begin{array}{l}\text { Hired labor } \\
\text { processors }\end{array}$ & $\begin{array}{l}\text { Processing } \\
\text { contractor }\end{array}$ & \\
\hline \multicolumn{5}{|l|}{ Traditional: } \\
\hline Palm oil & & 1200 & 800 & 2000 \\
\hline Palm kernel & & 875 & 2625 & 3500 \\
\hline By-products & & 506 & 506 & 1012 \\
\hline Total receipt in kind & & 2581 & 3931 & 6512 \\
\hline Cash receipt (feeding) & & 1150 & & 1150 \\
\hline Net receipts by personnel & & 3731 & $3931(2825)=1106$ & 4837 \\
\hline Net receipts by gender & 0 & 4837 & 4837 & \\
\hline \multicolumn{5}{|l|}{ Modern: } \\
\hline Palm oil & 250 & 1500 & 750 & 2500 \\
\hline Palm kernel & 200 & 200 & 3100 & 3500 \\
\hline By- products & 0 & 513 & 513 & 1026 \\
\hline Total receipts in kind & 450 & 2213 & 4363 & 7026 \\
\hline Cash receipts (feeding) & & 750 & & 750 \\
\hline Net receipts by personnel & 450 & 2963 & $4363(2575)=1788$ & 5201 \\
\hline Net receipts by gender & 450 & 4751 & 5201 & \\
\hline
\end{tabular}

Notes:

Values in brackets are the cash outflow from processing contractors. This covered payment for pre-processing expenses, cash payment in lieu of food,, transport and miscellaneous expenses. The revenue sources are palm oil, palm kernel and by-products. The categories of personnel are processing contractors, hired processors and processing machine owner.

Source: Data Analysis, 2004

\subsubsection{By gender}

The two categories of personnel (hired processors and processing contractors) involved in the traditional method were female and they earned all the revenue/income exclusive of males. The modern method involved obtaining the use of processing machines which were essentially owned by males as ninety four percent of the owners were male, thereby directing payment for the service rendered by processing machines to flow to males. Lack of financial resources prevented female ownership of the processing facility. For a processing run, females earned 4837 in the traditional method, which declined to 4751 in the modern method as a result of lower labour requirements in the modern method.

\subsubsection{By input substitution}

In the modern palm fruit processing method machine hour input was substituted for manual labour input. Three machine hours (two machine hours of digestion and one machine hour of palm kernel cracking) replaced ten man-days of human labour (three man-days of digestion and seven man-days of kernel cracking). This substitution reduced the 
processing duration of a processing run in the modern method relative to the traditional method, thereby releasing processors' time for other pressing activities.

\section{58 Attitudinal measure}

The distribution of users of processing machines by their attitudinal responses to the modern processing method is indicated in Table 7. A high proportion (85.51 per cent) of the processors had favourable attitudes towards the modern method. This group preferred it because of reduced drudgery, less labour requirements, shorter processing time and higher palm-oil extraction efficiency. The unfavorable attitude exhibited by the remaining percentage (14.49) was because the mechanised processing facilities are not located close to the palm fruit collection centre, necessitating the use of motor vehicles that are either expensive (transport fare) or not available. Also, the processing machine does not process less than a drum, thereby excluding small processors from using the facility. The processors expressed the need for the mechanisation of the palm fruit stripping stage to eliminate the associated drudgery. The use of the modern processing method by a significant percentage of the processors will in the aggregate result in improved palm oil production.

\section{Table 7}

Distribution of processors using modern method by attitudinal responses in Osun State, Nigeria

\begin{tabular}{|l|c|c|}
\hline Attitudes & Frequency & Percentage \\
\hline Favourable & 118 & 85.51 \\
\hline Unfavourable & 20 & 14.49 \\
\hline Total & 138 & 100 \\
\hline
\end{tabular}

Source: Data Analysis, 2004

\section{4 Summary and conclusion}

Nigeria, dissatisfied with its relative dwindling fortune in oil palm output, has, among other measures, promoted the adoption of small-scale oil palm produce extraction technology (modern method), which will hopefully bring about increased productivity over the traditional processing method, which is basically manual. This study identifies the processing stages that are mechanised in the field. It examines the implications of the technical change on the types and quality of oil palm produce, labour requirement, income to gender and market orientation. Also examined are the implications of the change on labour use efficiency, stakeholder groups, processing duration, and drudgery, volume of operation and attitude of users, which will aid decisionmaking on the superiority or otherwise of the modern method.
Primary data collected on the production resources and outputs of the two methods in Osun State of Nigeria were analysed using descriptive and inferential statistics, attitudinal measure, dominance and sensitivity analyses, and budgetary technique.

Results indicated that for modern processing methods only two (pounding and mashing of palm fruit and palm kernel cracking) out of ten processing stages identified were mechanised in the field. Users of the modern method indicated a dire need for the modernisation of the palm fruit stripping stage to eliminate the associated drudgery. The modern method dominated the traditional method and resulted in higher labour productivity, more income to processing contractors, greater market orientation, increased volume of operation, unchanged product types and quality. Other impacts are the creation of an additional group of stakeholders (machine owners), resilience to negative palm oil yield and machine charges, more favourable attitude, less drudgery and 
health hazards, less labour requirements and lower processing time than the traditional method. This therefore makes the modern method more preferable to a significant proportion of palm oil processors, which in turn will improve the palm oil production industry.

\section{References}

1 AJAKAIYE \& AKANDE. (1999) National Agricultural Research Programme in Nigeria: The Efficacy of Policy, A publication of the SocioEconomic Policy Research Component of the National Agricultural Research Project, Nigeria: 75.

2 AKINYEMIJU, A.O. \& ALIMI, T. (1988) "Economics of maize (Zea mays ) production under different weed control methods", Nigerian Journal of Weed Science, Nigeria, 2(1\&2): 51-55.

3 ALIMI, T., \& ALOFE, C.O. (1992)

"Profitability response of improved open pollinated maize varieties to nitrogen fertilizer levels", Journal of Rural Development in Nigeria, 4(1): 1-7.

4 ALIMI, T. \& AYANWALE, A.B. (1998) "An assessment of gender contributions in commercial palm oil production by traditional methods in Osun State, Nigeria", Nigerian Journal of Agric and Rural Management, ARMTI, 5(1): 1-11.

5 ALIMI, T.; OBISESAN, I.O. \& AKINYEMI, J.O. (1990) "Economic analysis of the performance of twelve cultivars of soybean Glycine Max (L) (Merrill) in Ife Agro-Climatic zone", Ife Journal of Agriculture, Nigeria, 2(1\& 2): 112-119.

6 ALIMI, T. \& MANYONG, V.M. (2000) Partial budgeting for on-farm research, IITA Research Guide, 65: 53.

7 BRIGGS, S. \& FARRIGTON, J. (1991) "Agricultural research and the rural poor: A review of social science analysis, IDRC, Ottawa, Canada.

8 CBN (1997) Central Bank of Nigeria Statistical Bulletin, Output of major agricultural commodities: 114-115.

9 CIMMYT (1988) From agronomic data to farmer recommendation: an economic training manual, Mexico, DF: 79.

10 DANIEL, W.W. \& TERRELL, J.C. (1979) Business Statistics - Basic concepts and methodology, $2^{\text {nd }}$ Edition, Houghton Mifflin Company: Boston: 217-224.

11 FABIYI, Y.L. (1979) Land tenure reforms in Nigeria: Implication of the land use decree (Act) for agricultural development, Ife Journal of Agriculture, 1(2): 235-257.

12 HARSH, S.B.; CONNOR, L.J. \& SCHWAB, G.D. (1981) Managing the Farm Business, Prentice-Hall Inc.: Englewood Clif: 190-193.

13 JIBOWO, A.A. (1993) "Factors Determining the Adequacy of Technological Innovations Among Farmers in Workshop Proceedings on Effective Transfer of Agricultural Technologies to Nigerian Farmers", Held at IITA Ibadan, November $30^{\text {th }}$ December $2^{\text {nd }} 1991: 124-143$.

14 JHINGHAN, M.L. (2003) The Economics of Development and Planning, $36^{\text {th }}$ Edition, Vrinda Publications (P) LTD: 1-22.

15 LADIPO, O.O. \& ADEYEMO, M.A. (1981) "Demand for mechanization service in food crop production in Oyo State Nigeria", Ife Journal of Agriculture, 3(1\&2): 82-89.

16 LEAVITT, H.J. (1978) Managerial Psychology An Introduction to Individuals, Pairs, and Groups in Organization, the University of Chicago Press, Chicago and London: 81-90.

17 MELLOR, J.W. (1966) the Economics of Agricultural Development, Cornell University Press: 3-5.

18 MUQTADA, M. (1975) “The Seed-Fertilizer Technology and Surplus Labour in Bangladesh Agriculture", The Bangladesh Dev. Studies, iii(4): 403-426.

19 MURPHY, D.J. (1994) Designer Oilseed Crops, VCH Press: Weinreim.

20 OGUNTADE, A.E. (1984) "An economic evaluation of the plantation system of oil palm production, A case study of the Okitipupa Oil Palm Company”, An unpublished M.Sc ppThesis in the Dept of Agric. Econ, O.AU, Ile-Ife.

21 OLAYIDE, S.O. \& HEADY, E.O. (1982) Introduction to Agricultural Production Economics, University of Ibadan, Ibadan University Press: Ibadan, Nigeria: 24-93.

22 OPEKE, L.K. (1992) Tropical tree crops, John Wiley and Sons. Chichester: New York: 251-274.

23 OYELARAN-OYEYINKA, B.; LADITAN, G.O.A. \& ESUBIYI, A.O. (1995) "Generation and utilisation of industrial innovation in Nigeria”, ATPS working paper, 8: 8-10.

24 STEEL, R.G.D. \& TORRIE (1960) Principles and Procedures of Statistics with Special Reference to Biological Sciences, McGraw-Hill Book Company, Inc: London: 420-425.

25 TAIWO, K.A.; OWOLARAFE, O.K.; SANNI, L.A.; JEJE, J.O.; ADELOYE, K. \& AJIBOLA. O.O. (2000) "Technological assessment of palm oil production in Osun and Ondo states of Nigeria”, Technovation, 20: 215-223. 